\title{
PENGEMBANGAN PRODUK READY TO USE THERAPEUTIC FOOD (RUTF) BERBENTUK BAR BERBAHAN KACANG HIJAU, SEREALIA, DAN MINYAK NABATI
}

\author{
Development of Ready to Use Therapeutic Food (RUTF) Bar Product Made from Mungbean, \\ Cereal, and Vegetable Oils
}

Reni Novia ${ }^{1}$, Budi Setiawan ${ }^{*}$, Sri Anna Marliyati ${ }^{1}$

${ }^{1}$ Departemen Gizi Masyarakat, Fakultas Ekologi Manusia, IPB University, Bogor, Indonesia

*E-mail: bsetiawan@apps.ipb.ac.id

\begin{abstract}
ABSTRAK
Pemberian produk RUTF (Ready to Use Therapeutic Food) merupakan salah satu solusi untuk mengatasi malnutrisi akut berat pada balita. Penelitian ini bertujuan untuk mengembangkan dan menganalisis produk RUTF berbentuk bar dari kacang hijau, serealia, dan minyak nabati untuk balita malnutrisi akut berat. Penelitian ini menggunakan Rancangan Acak Lengkap Faktorial dengan dua faktor dan dua ulangan. Faktor tersebut terdiri dari faktor A (kombinasi penggunaan tepung kacang hijau dengan jenis serealia yaitu tepung beras atau tepung jagung), dan faktor B (minyak nabati yaitu minyak kelapa atau minyak kelapa sawit). Penentuan formula terpilih didasarkan pada uji organoleptik (uji hedonik) dan kandungan gizi produk (energi dan protein). Hasil analisis uji hedonik menunjukkan bahwa atribut warna, aroma, rasa tekstur dan keseluruhan produk tidak berbeda nyata antar formula dan semua formula cenderung disukai panelis. Perlakuan kombinasi penggunaan tepung kacang hijau dengan serealia berpengaruh secara signifikan terhadap kandungan protein sedangkan perlakuan penggunaan minyak nabati berpengaruh secara signifikan terhadap kandungan energi produk. Hasil penelitian menunjukkan bahwa formula yang dipilih adalah formula A1B1 (kombinasi penggunaan tepung kacang hijau dengan tepung beras dan minyak kelapa) yang mengandung energi 522 kkal, 3,42\% kadar air, 2,32\% kadar abu, 13,57\% protein, 28,89\% lemak, 51,81\% karbohidrat, serat pangan 4,66\%, zat besi 13,82 $\mathrm{mg} / 100 \mathrm{~g}$, kalsium 348,24 mg/100g, daya cerna protein 94,93\%, dan aktivitas air 0,21. Formula A1B1 memenuhi persyaratan standar produk $R U T F$ untuk semua kandungan gizi dan aktivitas air kecuali kandungan air berdasarkan WHO (2007).
\end{abstract}

Kata kunci: kacang hijau, malnutrisi akut berat, minyak nabati, RUTF, serealia

\begin{abstract}
Providing RUTF (Ready to use therapeutic food) product is one of the solution to overcome severe acute malnutrition in children under five years. The study aimed was to develop and analyze RUTF products in the form of bar made from mung bean, cereal, and vegetable oils for severe acute malnutrition children under five years. This study used a completely randomized factorial design (RALF) with two factors and two replications. The factors consisted of factor $A$ (the combination of mung bean flour with the type of cereal namely rice flour or, cornflour), and factor $B$ (vegetable oil namely coconut oil or palm oil). The determination of selected formula was based on organoleptic test and nutrient content of product (energy and protein). The results of the hedonic test analysis showed that the attributes of color, aroma, taste, texture and overall product were not significantly different between formulas and all formulas tended to be favored by panelists. The combination treatment using mung bean flour with cereals had a significant effect on the protein content, while the use of vegetable oil had a significant effect on the energy content of the product. The result of this study showed that the selected formula was A1B1 formula (the combination mung bean flour with rice flour and coconut oil) which contained 522 kcal energy; $3.42 \%$ moisture content; $2.32 \%$ ash content; $13.57 \%$ protein; $28.89 \%$ fat; $51.81 \%$ carbohydrate; $4.66 \%$ dietary fiber, $13.82 \mathrm{mg} / 100 \mathrm{~g}$ iron, $348.24 \mathrm{mg} / 100 \mathrm{~g}$ calcium, $94.93 \%$ protein digestibility and 0.21 water activity. Formula A1B1 has fulfilled the requirements of the standard RUTF product for all nutritional content and water activity except for the moisture content base on WHO (2007).
\end{abstract}

Keywords: mung bean, severe acute malnutrition, vegetable oil, RUTF, cereal 


\section{PENDAHULUAN}

Indonesia merupakan salah satu negara berkembang yang memiliki masalah triple burden malnutrition yaitu masalah kurang gizi, kelebihan gizi dan defisiensi mikronutrien (UNICEF, 2020). Malnutrisi merupakan masalah gizi yang terjadi karena adanya ketidakseimbangan antara asupan dan kebutuhan gizi. Malnutrisi yang terjadi karena penurunan asupan zat gizi atau kualitas gizi dalam waktu yang relatif singkat dan disertai dengan penyebab patologis disebut malnutrisi akut. Malnutrisi yang terjadi karena penurunan asupan zat gizi dalam waktu yang relatif lama dan menyebabkan gangguan pertumbuhan sering disebut malnutrisi kronis contohnya stunting pada balita (Lenters et al., 2016).

Malnutrisi akut terbagi menjadi dua yaitu malnutrisi akut sedang dan malnutrisi akut berat. Malnutrisi akut sedang ditandai dengan nilai $\mathrm{z}$ score $\mathrm{BB} / \mathrm{TB}$ berada diantara $-3 \mathrm{SD}$ dan $-2 \mathrm{SD}$ atau lingkar lengan atas antara 115 dan $125 \mathrm{~mm}$. Sedangkan malnutrisi akut berat ditandai dengan nilai z score $\mathrm{BB} / \mathrm{TB}$ kurang dari $-3 \mathrm{SD}$, atau lingkar lengan atas kurang dari $115 \mathrm{~mm}$, dan ada atau tidak adanya edema bilateral (Lenters et al., 2016). Sebanyak $10,2 \%$ balita di Indonesia pada tahun 2018 mengalami malnutrisi akut (malnutrisi akut sedang 6,7\% dan malnutrisi akut berat 3,5\%) (Kemenkes, 2018). Berdasarkan batas ambang masalah kesehatan masyarakat, masalah malnutrisi akut di Indonesia masih termasuk kategori serius yaitu berada pada rentang prevalensi $10-14 \%$ (WHO, 2010).

Apabila masalah malnutrisi akut ini tidak dapat diatasi dengan baik maka akan dapat menyebabkan dampak negatif pada balita diantaranya dapat meningkatkan risiko kematian, morbiditas dan kecacatan, lebih mudah terkena penyakit infeksi, penurunan psikomotor, dan penurunan kemampuan kognitif anak (NDPC, 2016; UNICEF, 2013). Salah satu upaya mengatasi masalah ini adalah pemberian RUTF (Ready to use therapeutic food) (Hendrixson et al., 2020). RUTF merupakan produk padat energi yang diperkaya dengan zat gizi mikro yang diberikan kepada balita malnutrisi akut berat tanpa komplikasi atau tanpa penyakit penyerta (Miele et al., 2020). Beberapa penelitian telah membuktikan produk RUTF dapat meningkatkan pemulihan malnutrisi akut berat tanpa komplikasi dari $25-50 \%$ menjadi $80-90 \%$ (Ciliberto et al., 2005; Linneman et al., 2007).

Pengembangan produk RUTF di dianjurkan menggunakan bahan pangan tinggi zat gizi, terjangkau, dapat diterima dan dianjurkan menggunakan bahan pangan lokal. Beberapa bahan pangan lokal yang berpotensi digunakan dalam pengembangan produk RUTF yaitu kacang hijau, serealia (beras, jagung), minyak nabati (minyak kelapa dan kelapa sawit).

Kacang hijau mengandung protein yang tinggi dan mudah dicerna serta mengandung mineral yang relatif tinggi, dapat mengurangi kejadian perut kembung, bersifat hypoallergic, serta tidak menimbulkan efek samping seperti diare pada balita (Dahiya et al., 2014; Hou et al., 2019; YiShen et al., 2018). Kacang hijau dikombinasikan dengan pangan serealia (beras dan jagung) dengan tujuan agar saling melengkapi profil asam amino produk. Kacang hijau mengandung rendah asam amino sulfur (metionin dan sistein) tetapi tinggi asam amino lisin sedangkan pangan serealia (beras dan jagung) mengandung tinggi asam amino sulfur (metionin dan sistein) dan rendah asam amino lisin sehingga apabila kacang hijau dikombinasikan dengan pangan serealia (beras dan jagung) maka dapat saling melengkapi profil asam amino (YiShen et al., 2018).

Beras mengandung karbohidrat yang tinggi, serta tinggi asam amino metionin dan sistein, serta bersifat mudah dicerna (Rohman et al., 2014; Wu et al., 2019). Beras mengandung asam amino lisin yang rendah tetapi jika dibandingkan dengan jenis pangan serealia yang lain, asam amino lisin pada beras lebih tinggi dan hal ini dapat dikombinasikan dengan kacang hijau agar profil asam amino menjadi lebih lengkap (Michaelsen et al., 2009).

Selain beras, pangan serealia yang dapat dikombinasikan dengan kacang hijau adalah jagung. Jagung yang digunakan yaitu jagung kuning, tidak hanya mengandung karbohidrat sebagai sumber zat gizi, namun juga mengandung beta karoten atau provitamin A, serta mengandung tinggi asam amino metionin dan sistein yang apabila dikombinasikan dengan kacang hijau profil asam amino dapat saling melengkapi (Budiarti et al., 2017; Shah et al., 2016).

Minyak nabati yang digunakan adalah jenis minyak nabati yang mengandung tinggi energi 
yaitu minyak kelapa dan minyak kelapa sawit. Selain mengandung tinggi energi, minyak kelapa juga memiliki sifat antimikroba, antijamur, antivirus dan antibakteri, serta mengandung tinggi asam laurat yang mudah diserap dan dicerna oleh tubuh dan tidak membebani saluran gastointestinal (Mikołajczak, 2017; Vala \& Kapadiya, 2014). Minyak kelapa sawit selain mengandung tinggi energi, juga mengandung vitamin $\mathrm{E}$, perkursor vitamin $\mathrm{A}$ dan membantu pemeliharaan jaringan dan mendorong pertumbuhan pada membran sel (Boateng et al., 2016).

Menurut Sigh et al. (2018), jenis-jenis produk $R U T F$ yang dikembangkan di dunia adalah $R U T F$ pasta/krim, biskuit/compress bar, dan wafer pasta. Pengembangan produk pasta dan krim sudah banyak dikembangkan dan sudah ada dikembangkan di Indonesia, sedangkan untuk pengembangan produk wafer dan RUTF compress bar masih sedikit dikembangkan di dunia dan belum ada dikembangkan di Indonesia. Oleh karena itu pada penelitian ini saya mengembangkan produk RUTF berbentuk bar/compress bar. Keunggulan pengembangan dalam bentuk bar yaitu dapat dikonsumsi langsung, praktis, mudah hancur saat ditekan, dan memiliki umur simpan yang cukup lama (FAO, 2015).

Produk RUTF berbentuk bar ini tidak melalui proses pemanggangan menggunakan oven seperti produk food bar yang biasa dikembangkan di Indonesia akan tetapi beberapa bahan tertentu disangrai dan campuran semua bahan dilakukan pengepresan agar berbentuk bar. Tujuan penelitian ini adalah untuk mengembangkan dan menganalisis produk Ready-to-Use Therapeutic Food (RUTF) berbentuk bar berbahan kacang hijau, serealia, dan minyak nabati untuk balita malnutrisi akut berat.

\section{METODE}

Desain penelitian ini yaitu experimental menggunakan Rancangan Acak Lengkap Faktorial (RALF) dengan 2 faktor perlakuan dan 2 ulangan. Faktor perlakuan yang diberikan yaitu faktor A (kombinasi penggunaan tepung kacang hijau dengan serealia (tepung beras atau tepung jagung) dan faktor B (penggunaan minyak nabati (minyak kelapa atau minyak kelapa sawit). Penelitian dilakukan bulan Desember 2020
- Mei 2021 di Laboratorium Pengolahan dan Percobaan Makanan, Laboratorium Organoleptik, Laboratorium Kimia dan Analisis Makanan Departemen Gizi Masyarakat Fakultas Ekologi Manusia IPB University, Laboratorium Ilmu Nutrisi dan Ternak Perah Departemen Ilmu Nutrisi dan Teknologi Pakan Fakultas Peternakan IPB University, SEAFAST Center IPB University dan Laboratorium Saraswati Indo Genetech (SIG), Bogor.

Bahan pangan yang digunakan adalah tepung kacang hijau, tepung beras, tepung jagung, minyak kelapa, minyak kelapa sawit, susu bubuk full cream, gula halus, maltodekstrin dan vitamin mineral mix.

Penelitian ini terdiri dari beberapa tahapan yaitu formulasi, pembuatan RUTF berbentuk bar, uji organoleptik, analisis kandungan protein dan perhitungan energi semua formula, penentuan formula terpilih, serta analisis kandungan zat gizi (kadar air, abu, lemak, protein, karbohidrat, serat pangan, zat besi, kalsium), daya cerna protein, perhitungan energi dan analisis aktivitas air $\left(\mathrm{a}_{\mathrm{w}}\right)$ formula terpilih. Formulasi produk dilakukan berdasarkan hasil modifikasi produk HEBI yaitu produk RUTF berbentuk bar yang dikembangkan di negara Vietnam untuk mengatasi masalah malnutrisi akut pada balita (Wieringa et al., 2013).

Proses modifikasi dilakukan dengan mempertimbangkan kandungan gizi sesuai persyaratan standar produk RUTF. Menurut FAO (2019) dalam pengembangan produk RUTF dianjurkan kandungan asam amino pembatas produk mendekati skor 100 dan memiliki nilai PDCAAS (Protein digestibility Corrected Amino Acid Score $) \geq 90$ sehingga dalam proses formulasi diperlukan perhitungan estimasi asam amino dan nilai PDCAAS sebagai pertimbangan agar memenuhi anjuran FAO. Selain itu, pada saat penentuan formulasi juga mempertimbangkan aspek organoleptik produk.

Kombinasi tepung kacang hijau dan serealia (tepung beras dan jagung) menyesuaikan dengan estimasi terpenuhinya kandungan zat gizi berdasarkan standar produk RUTF dan mempertimbangkan kandungan asam amino pembatas mendekati nilai 100 , serta estimasi nilai PDCAAS mencapai $\geq 90$. Oleh karena itu, 
perbandingan kombinasi tepung kacang hijau dengan tepung beras sebesar $22.00: 13,25 \mathrm{~g}$ sedangkan kombinasi tepung kacang hijau dan tepung jagung sebesar $21.00: 14,25 \mathrm{~g}$. Jumlah penggunaan minyak nabati (minyak kelapa dan kelapa sawit) sebanyak 22,5 gram dengan pertimbangan hasil estimasi perhitungan agar memenuhi standar kandungan gizi produk RUTF terutama kandungan energi dan lemak.

Protein yang berkualitas tinggi dapat didapatkan dengan formulasi RUTF mengandung minimal $50 \%$ protein susu dan penggunaannya meningkatkan daya cerna protein dan nilai PDCAAS ( $\geq 90)$ (FAO, 2019). Penggunaan susu sebesar 25-35\% (Owino et al., 2012). Penggunaan sumber protein hewani yang lebih tinggi lebih efektif meningkatkan pemulihan malnutrisi akut berat. Pada penelitian intervensi pemberian RUTF $25 \%$ susu lebih efektif dan memiliki kenaikan berat badan dan tinggi badan lebih tinggi dibandingkan pemberian RUTF 10\% susu (Oakley et al., 2010). Oleh karena itu penggunaan susu full cream pada penelitian ini sebesar $35 \mathrm{~g}$ (33,5\% total formula). Jumlah penggunaan susu, gula halus, maltodekstrin, dan vitamin mineral mix juga mempertimbangkan estimasi pemenuhan kandungan gizi standar RUTF dan hasil organoleptik. Formulasi RUTF berbentuk bar disajikan pada Tabel 1.

Proses pembuatan RUTF berbentuk bar diawali dengan persiapan bahan pangan dan penyangraian tepung kacang hijau, tepung beras serta tepung jagung. Tepung kacang hijau disangrai \pm 15 menit hingga mencapai suhu $130^{\circ} \mathrm{C}$ sedangkan tepung beras dan tepung jagung disangrai \pm 10 menit hingga mencapai suhu $115^{\circ} \mathrm{C}$ dan selanjutnya masing-masing tepung diayak. Proses berikutnya adalah penimbangan bahan sesuai dengan berat setiap formula. Bahan-bahan kering seperti tepung kacang hijau, tepung beras atau jagung, gula halus, maltodekstrin, susu bubuk full cream dan vitamin mineral mix dicampur hingga rata. Tahapan selanjutnya campuran bahan kering dicampur hingga rata dengan minyak kelapa atau minyak kelapa sawit kemudian campuran bahan ditimbang sesuai standar porsi lalu dicetak dan dipress (tekanan 1 ton $/ \mathrm{cm}^{2}$ selama 1 menit). Setelah pengepresan, proses pembuatan produk RUTF berbentuk bar sudah selesai dan sudah dapat untuk dikonsumsi (Nga et al., 2013).

Tahapan berikutnya semua formula dilakukan uji organoleptik menggunakan metode $10 \mathrm{~cm}$ hybrid hedonic scale yaitu skala garis linier yang menyajikan garis sepanjang $10 \mathrm{~cm}$ di setiap atribut dan memberikan keterangan skala yang paling ekstrim di setiap ujung garis. Metode ini memiliki beberapa keunggulan yaitu tidak terbatas pada sejumlah kategori sehingga panelis bebas menilai produk, menghindari kesalahan psikologis pada saat penilaian serta menghasilkan data kontinius sehingga analisis dapat dilakukan secara parametrik maupun nonparametrik (Villanueva et al., 2005). Kegiatan uji ini dilakukan pada 30 orang panelis semi terlatih yaitu mahasiswa/i IPB University yang sudah mendapatkan materi mengenai organoleptik dan sudah pernah melakukan uji organoleptik. Selanjutnya semua formula dianalisis

Tabel 1. Formulasi RUTF Berbentuk Bar

\begin{tabular}{lcccc}
\hline \multicolumn{1}{c}{ Bahan } & A1B1 & A1B2 & A2B1 & A2B2 \\
\hline Tepung kacang hijau (g) & 22,00 & 22,00 & 21,00 & 21,00 \\
Tepung beras (g) & 13,25 & 13,25 & 0,00 & 0,00 \\
Tepung jagung (g) & 0,00 & 0,00 & 14,25 & 14,25 \\
Minyak kelapa (g) & 22,50 & 0,00 & 22,50 & 0,00 \\
Minyak kelapa sawit (g) & 0,00 & 22,50 & 0,00 & 22,50 \\
Susu bubuk full cream (g) & 35,00 & 35,00 & 35,00 & 35,00 \\
Gula halus (g) & 1,00 & 1,00 & 1,00 & 1,00 \\
Maltodekstrin (g) & 10,00 & 10,00 & 10,00 & 10,00 \\
Vitamin mineral mix $(\mathrm{g})$ & 0,75 & 0,75 & 0,75 & 0,75 \\
Total & 104,5 & 104,5 & 104,5 & 104,5 \\
\hline
\end{tabular}

Keterangan: A1B1 (kombinasi tepung kacang hijau dengan tepung beras, penggunaan minyak kelapa), A1B2 (kombinasi tepung kacang hijau dengan tepung beras, penggunaan minyak kelapa sawit), A2B1 (kombinasi tepung kacang hijau dengan tepung jagung, penggunaan minyak kelapa), A2B2 (kombinasi tepung kacang hijau dengan tepung jagung, penggunaan minyak kelapa sawit). 
kandungan protein (SNI 01-2891-1992) dan dihitung kandungan energinya (Winarno, 2008).

Penentuan formula terpilih ditentukan berdasarkan hasil signifikansi analisis statistik uji organoleptik berupa uji hedonik (atribut keseluruhan) semua formula sebagai pertimbangan utama, apabila hasil uji organoleptik tidak berbeda nyata maka pertimbangan berikutnya adalah hasil analisis kandungan energi dan protein semua formula.

Formula terpilih selanjutnya dilakukan analisis kadar air metode oven, kadar abu total, kadar protein metode kjeldhal dan kadar lemak metode soxhlet (SNI 01-2891-1992), kadar karbohidrat metode by difference (Andarwulan et al., 2011), serat pangan metode enzimatis gravimetri (AOAC Official Method 991,43), kadar mineral (Fe dan $\mathrm{Ca}$ ) metode AAS (Atomic Absorption Spectrophotometer) (AOAC, 2005; Nielsen, 2010), daya cerna protein metode in vitro (Saunders et al., 1973), energi (Winarno, 2008) dan analisis aktivitas air $\left(\mathrm{a}_{\mathrm{w}}\right)$ menggunakan Aw meter (AOAC Official Method 978.18).

Data penelitian diolah menggunakan Microsoft Excel 2016 dan SPSS 25.0 for Windows. Data uji organoleptik, kandungan energi dan protein dianalisis dengan menggunakan uji Twoway ANOVA. Hasil analisis kadar air, abu, lemak, protein, karbohidrat, energi, serat pangan, zat besi, kalsium, daya cerna protein dan aktivitas air $\left(\mathrm{a}_{\mathrm{w}}\right)$ produk RUTF berbentuk bar formula terpilih disajikan dalam bentuk rata-rata.

\section{HASIL DAN PEMBAHASAN}

\section{Analisis Uji Organoleptik dan Kandungan Gizi untuk Menentukan Formula Terpilih}

Penentuan formula terpilih produk RUTF berbentuk bar ditentukan berdasarkan hasil signifikansi analisis statistik uji organoleptik berupa uji hedonik (atribut keseluruhan) sebagai pertimbangan utama. Analisis uji organoleptik yang dilakukan yaitu uji hedonik atau tingkat kesukaan terhadap produk dan menilai karakteristik produk. Hasil uji statistik pada Tabel 2 menunjukkan bahwa faktor A (kombinasi penggunaan tepung kacang hijau dengan jenis serealia), faktor B (penggunaan jenis minyak nabati), serta interaksi antar kedua faktor tidak berpengaruh secara signifikan $(\mathrm{p}>0,05)$ terhadap tingkat kesukaan panelis terhadap atribut warna, aroma, rasa, tekstur dan keseluruhan produk. Berdasarkan analisis statistik juga diketahui bahwa atribut warna, aroma, rasa, tekstur dan keseluruhan produk tidak berbeda nyata antar formula dan cenderung disukai oleh panelis.

Hasil uji organoleptik menunjukkan karakteristik warna produk pada formula dengan kombinasi tepung kacang hijau dengan beras dan menggunakan minyak nabati cenderung berwarna kuning keputihan sedangkan formula dengan kombinasi tepung kacang hijau dengan jagung dan menggunakan minyak nabati cenderung berwarna kuning muda. Selain itu, produk RUTF bar cenderung terasa manis, creamy, memiliki tekstur yang kompak, tidak terlalu keras dan

Tabel 2. Data Hasil Uji Organoleptik (Uji Hedonik), Kandungan Energi dan Protein RUTF Berbentuk Bar

\begin{tabular}{lcccc}
\hline \multicolumn{1}{c}{$\begin{array}{c}\text { Uji Organoleptik (Uji Hedonik), } \\
\text { Kandungan Energi dan Protein }\end{array}$} & A1B1 & A1B2 & A2B1 & A2B2 \\
\cline { 2 - 5 } & & & & \\
\hline Uji Organoleptik (Uji Hedonik) & $7,38 \pm 1,18^{\mathrm{a}}$ & $7,36 \pm 1,17^{\mathrm{a}}$ & $7,12 \pm 1,40^{\mathrm{a}}$ & $7,19 \pm 1,42^{\mathrm{a}}$ \\
$\quad$ Warna* & $7,32 \pm 1,40^{\mathrm{a}}$ & $6,78 \pm 1,54^{\mathrm{a}}$ & $7,41 \pm 1,48^{\mathrm{a}}$ & $6,88 \pm 1,95^{\mathrm{a}}$ \\
Aroma* $^{*}$ & $6,97 \pm 1,69^{\mathrm{a}}$ & $7,21 \pm 1,54^{\mathrm{a}}$ & $7,33 \pm 1,63^{\mathrm{a}}$ & $6,96 \pm 1,66^{\mathrm{a}}$ \\
Rasa* $^{\text {Tekstur* }}$ & $6,72 \pm 1,85^{\mathrm{a}}$ & $7,10 \pm 1,44^{\mathrm{a}}$ & $6,74 \pm 1,86^{\mathrm{a}}$ & $6,30 \pm 1,98^{\mathrm{a}}$ \\
Keseluruhan* & $7,32 \pm 1,11^{\mathrm{a}}$ & $7,30 \pm 1,35^{\mathrm{a}}$ & $7,40 \pm 1,40^{\mathrm{a}}$ & $6,97 \pm 1,59^{\mathrm{a}}$ \\
\hline Kandungan Energi dan Protein & & & & \\
Protein & $13,57 \pm 0,23^{\mathrm{Aa}}$ & $13,60 \pm 0,16^{\mathrm{Aa}}$ & $13,28 \pm 0,04^{\mathrm{Ba}}$ & $13,26 \pm 0,06^{\mathrm{Ba}}$ \\
Energi & $522 \pm 0,37^{\mathrm{Aa}}$ & $520 \pm 0,17^{\mathrm{Ab}}$ & $522 \pm 0,27^{\mathrm{Aa}}$ & $520 \pm 0,36^{\mathrm{Ab}}$ \\
\hline
\end{tabular}

Keterangan: Huruf berbeda pada baris yang sama menunjukan perbedaan yang signifikan $(\mathrm{p}<0.05)$, ${ }^{*}$ Tidak terdapat pengaruh yang signifikan pada interaksi antar perlakuan dan masing-masing perlakuan terhadap hasil analisis kandungan protein atau energi, ${ }^{\mathrm{A}-\mathrm{B}}$ Faktor perlakuan kombinasi penggunaan tepung kacang hijau dengan jenis serealia yaitu tepung beras dan jagung (selain yang diberi tanda*), ${ }^{\mathrm{a}-\mathrm{b}}$ Faktor perlakuan penggunaan jenis minyak nabati yaitu minyak kelapa dan minyak kelapa sawit (selain yang diberi tanda *) 
mudah hancur saat ditekan, mudah untuk ditelan, mouthfeel cenderung halus serta aroma langu, rasa pahit dan aftertaste pahit cenderung sangat lemah. Produk RUTF untuk balita malnutrisi akut berat dianjurkan memiliki tekstur yang tidak keras, mudah hancur saat ditekan, memiliki mouthfeel yang halus, mudah untuk ditelan, memiliki rasa yang cenderung manis, tidak memiliki aroma langu atau aroma yang tidak menyenangkan. Berdasarkan uji organoleptik produk RUTF berbentuk bar ini sudah memenuhi anjuran tersebut.

Selain penentuan formula terpilih berdasarkan uji organoleptik, penentuan formula terpilih juga mempertimbangkan hasil analisis statistik kandungan energi dan protein. Kandungan energi dan protein dimasukkan dalam pertimbangan penentuan formula terpilih dikarenakan kandungan energi dan protein sangat penting untuk balita karena berperan dalam membantu pertumbuhan dan perkembangan balita serta membantu dalam metabolisme sistem kekebalan tubuh. Kandungan energi juga dapat membantu peningkatan berat badan balita termasuk pada balita malnutrisi akut berat (Diniyyah \& Nindya, 2017; Dipasquale et al., 2020). Hasil analisis kandungan energi dan protein disajikan pada Tabel 2.

Kandungan energi dan protein pada produk semua formula memenuhi standar produk RUTF berdasarkan WHO (2007) dan UNICEF (2019). Hasil uji statistik two-way ANOVA menunjukkan bahwa faktor A (kombinasi penggunaan tepung kacang hijau dengan jenis serealia) dan interaksi antara faktor A dan B tidak berpengaruh secara signifikan $(p>0,05)$ terhadap kandungan energi sedangkan faktor $B$ (penggunaan jenis minyak nabati) berpengaruh secara signifikan $(p<0,05)$ terhadap kandungan energi produk. Hasil analisis juga menunjukkan kandungan energi formula yang dibuat dari minyak kelapa lebih tinggi secara nyata dibandingkan dengan minyak kelapa sawit. Hal ini disebabkan karena kandungan energi minyak kelapa lebih tinggi dibandingkan dengan minyak kelapa sawit. Kandungan energi per $100 \mathrm{~mL}$ yaitu minyak kelapa sawit sebesar 810 kkal sedangkan minyak kelapa sebesar $836 \mathrm{kkal}$.

Hasil uji statistik two-way ANOVA juga menunjukkan bahwa faktor $B$ (penggunaan jenis minyak nabati) dan interaksi antara faktor A dan B tidak berpengaruh secara signifikan $(\mathrm{p}>0,05)$ terhadap kandungan protein sedangkan faktor A (kombinasi penggunaan tepung kacang hijau dengan jenis serealia) berpengaruh secara signifikan $(\mathrm{p}<0,05)$ terhadap kandungan protein produk. Hasil analisis juga menunjukkan formula produk yang dibuat dari kombinasi tepung kacang hijau dengan tepung beras lebih tinggi secara nyata dibandingkan dengan kombinasi tepung kacang hijau dan tepung jagung.

Hal ini disebabkan karena jumlah penggunaan tepung kacang hijau yang dikombinasikan dengan tepung beras sebanyak 22 gram dan jumlah ini lebih tinggi dibandingkan dengan jumlah tepung kacang hijau yang dikombinasikan dengan tepung jagung yaitu sebanyak 21 gram. Selain itu kandungan protein tepung kacang hijau lebih tinggi dibandingkan dengan tepung beras dan jagung sehingga ketika jumlah tepung kacang hijau yang digunakan lebih tinggi maka akan berkontribusi dalam meningkatkan kandungan protein produk. Kandungan protein per 100 gram bahan tepung kacang hijau, tepung beras dan tepung jagung pada penelitian ini secara berurut adalah sebesar 24,40 gram, 6.,26 gram dan 6,84 gram.

Berdasarkan pertimbangan hasil analisis statistik terhadap data uji organoleptik berupa uji hedonik (atribut keseluruhan), kandungan energi dan protein dari semua formula RUTF berbentuk bar diketahui bahwa formula A1B1 merupakan formula terpilih. Hal ini karena hasil analisis uji hedonik (keseluruhan) tidak menunjukkan perbedaan yang nyata pada semua formula, sehingga setiap formula memiliki peluang yang sama untuk dipilih sebagai formula terpilih dengan tahapan pertimbangan selanjutnya berdasarkan kandungan energi dan protein.

Hasil analisis statistik menunjukkan kandungan energi formula A1B1 tidak berbeda nyata dengan formula $\mathrm{A} 2 \mathrm{~B} 1$ akan tetapi berbeda nyata lebih tinggi dibandingkan dengan formula A1B2 dan A2B2. Kandungan protein formula A1B2 lebih tinggi dan tidak berbeda nyata dengan formula A1B1, akan tetapi berbeda nyata lebih tinggi dari formula A2B1 dan A2B2. Berdasarkan hasil analisis tersebut formula A1B1 mengandung energi dan protein yang tinggi dan dapat ditetapkan sebagai formula terpilih.

Kandungan zat gizi formula terpilih disajikan pada Tabel 3. Hasil analisis menunjukkan 
Tabel 3. Kandungan Zat Gizi, Energi, Daya Cerna Protein dan Aktivitas Air Produk RUTF Berbentuk Bar Formula Terpilih

\begin{tabular}{lccc}
\hline \multicolumn{1}{c}{ Kandungan Gizi } & Formula Terpilih & Standar Umum RUTF & Standar RUTF biscuit/compress bar $* * *$ \\
\hline Kadar air (\%) & $3,42 \pm 0,06$ & Maksimal 2,5* & Maksimal 4 \\
Kadar abu (\%) & $2,32 \pm 0,01$ & - & Maksimal 5 \\
Protein (\%) & $13,57 \pm 0,23$ & $12,8-16,2^{*}$ & $12,3-15,5$ \\
Lemak (\%) & $28,89 \pm 0,04$ & $25,8-36,3^{*}$ & $24,8-33,0$ \\
Karbohidrat (\%) & $51,81 \pm 0,21$ & - & $44,5-59,9$ \\
Energi (kkal) & $522 \pm 0,37$ & $520-550^{*}$ & Minimal $500 \mathrm{kkal}$ \\
Serat pangan (\%) & $4,66 \pm 0,33$ & $<5,00^{*}$ & $<5,00$ \\
Zat besi (mg/100g) & $13,82 \pm 0,01$ & $10-14^{*}$ & $10-14$ \\
Kalsium (mg/100g) & $348,24 \pm 4,48$ & $300-600^{*}$ & $300-600$ \\
Daya cerna protein $(\%)$ & $94,93 \pm 0,15$ & - & - \\
Aktivitas air $\left(\mathrm{a}_{\mathrm{w}}\right)$ & $0,21 \pm 0,02$ & Maks. $0,6^{* *}$ & Maksimal 0,6 \\
\hline
\end{tabular}

Keterangan : *WHO (2007), ** FAO (2020), *** UNICEF (2019), - Tidak tersedia

kadar abu, protein, lemak, karbohidrat, energi, serat pangan, zat besi, kalsium dan aktivitas air RUTF formula terpilih memenuhi persyaratan standar produk RUTF bentuk biscuit/compress bar (UNICEF, 2019) dan juga memenuhi standar umum semua kandungan gizi kecuali kadar air produk RUTF (WHO, 2007).

Kadar air merupakan komponen penting dalam produk pangan karena mempengaruhi pertumbuhan mikroorganisme. Kadar air yang rendah akan menurunkan pertumbuhan mikroorganisme dan meningkatkan densitas energi sehingga baik untuk balita malnutrisi akut berat (Michaelsen et al., 2009). Kadar air produk formula terpilih lebih tinggi dibandingkan dengan produk RUTF bar (HEBI) penelitian sebelumnya yang memiliki kadar air 2,5\% (Nga et al., 2013) dan 2,4\% (Wieringa et al., 2013). Menurut Winarno (2008), ketika suatu produk makanan mengandung kadar air antara 3-7\% masih tergolong cukup rendah dan dapat mengurangi terjadinya pertumbuhan mikroorganisme serta reaksi kimia yang dapat merusak produk. Selain itu, kadar air dapat mempengaruhi uji organoleptik produk seperti tekstur produk (Nurhusna et al., 2020). Kadar air produk masih tergolong cukup rendah karena adanya proses penyangraian tepung kacang hijau dan tepung beras yang menyebabkan kadar air tepung menjadi berkurang.

Hasil analisis kadar abu formula terpilih adalah sebesar 2,32\%. Kadar abu dapat mengasumsikan kadar mineral dalam produk makanan yang menunjukkan semakin tinggi kadar abu semakin tinggi kadar mineral produk (Andarwulan et al., 2011). Protein dibutuhkan tubuh untuk struktur, fungsi,dan regulasi jaringan tubuh dan organ (Khan et al., 2017). Menurut Diniyyah dan Nidya (2017), asupan protein pada balita sangat penting diperhatikan dan harus terpenuhi agar membantu proses pertumbuhan, perkembangan, serta membantu metabolisme kekebalan tubuh balita. Hasil analisis kadar protein sebesar 13,57\%. Kadar protein produk formula terpilih pada penelitian ini lebih tinggi dibandingkan dengan produk RUTF dalam bentuk wafer (NumTrey Wafer) yang mengandung kadar protein sebesar 12,27 $\mathrm{g}$ (Sigh et al., 2018). Akan tetapi kandungan protein formula terpilih lebih rendah dibandingkan dengan produk RUTF bar (HEBI) yang mempunyai kadar protein sebesar 15,33 g (Nga et al., 2013), 16,41 g (Wieringa et al., 2013) serta juga lebih rendah dibandingkan dengan produk RUTF dalam bentuk biskuit bar (BP-100) yang memiliki kandungan protein sebesar 14,68 g (Sigh et al., 2018). Bahan pangan yang berkontribusi terhadap kandungan protein pada produk formula terpilih adalah tepung kacang hijau, tepung beras, dan susu full cream.

Lemak merupakan salah satu nutrisi penting untuk dikonsumsi balita. Selain berfungsi sebagai sumber energi, lemak juga berfungsi sebagai pelarut vitamin A, D, E, K serta penambahannya pada makanan akan memengaruhi rasa dan tekstur makanan (Sharlin \& Edelstein, 2014). Kandungan lemak yang tinggi dapat meningkatkan densitas energi karena lemak berkontribusi memberikan 
energi yang lebih banyak dibandingkan protein dan karbohidrat (Michaelsen et al., 2009).

Hasil analisis kadar lemak produk RUTF berbentuk bar formula terpilih adalah sebesar $28,89 \%$. Kadar lemak produk formula terpilih lebih tinggi dibandingkan dengan produk RUTF dalam bentuk wafer (NumTrey Wafer) yang mengandung kadar lemak sebesar 27,89 g (Sigh et al., 2018). Akan tetapi lebih rendah dibandingkan dengan produk RUTF bar (HEBI) yang memiliki kadar lemak 34,67 g (Nga et al., 2013), 35,68 g (Wieringa et al., 2013) serta juga lebih rendah dibandingkan dengan produk RUTF berbentuk biskuit bar (BP-100) yang memiliki kandungan lemak sebesar 30,33 g (Sigh et al., 2018). Bahan pangan yang berkontribusi terhadap kandungan lemak formula terpilih adalah minyak kelapa (93 $\mathrm{g} / 100 \mathrm{ml})$, susu full cream $(28,57 \mathrm{~g} / 100 \mathrm{~g})$, tepung kacang hijau $(24,4 \mathrm{~g} / 100 \mathrm{~g})$ dan tepung beras $(0,64$ $\mathrm{g} / 100 \mathrm{~g})$.

Kadar karbohidrat dalam produk RUTF diperlukan oleh balita sebagai sumber energi, penyuplai dalam membantu proses pertumbuhan, fungsi tubuh dan pelaksanaan aktivitas (Sharlin \& Edelstein, 2014). Selain itu, kadar karbohidrat juga mempengaruhi organoleptik produk seperti warna, rasa dan tekstur (Sihab et al., 2017). Karbohidrat dapat mempengaruhi warna produk karena adanya reaksi Maillard yang menghasilkan warna cenderung lebih coklat atau lebih pekat, selain itu reaksi Maillard ini juga dapat mempengaruhi rasa pada produk (Nurhusna et al., 2020). Kandungan karbohidrat juga dapat meningkatkan tekstur kekerasan pada suatu produk seperti maltodekstrin dan jenis karbohidrat yang tidak dapat dicerna oleh tubuh (Sihab et al., 2017).

Hasil analisis kadar karbohidrat produk formula terpilih sebesar $51.81 \%$. Kadar karbohidrat formula terpilih lebih tinggi dibandingkan dengan produk RUTF dalam bentuk wafer (NumTrey Wafer) dan RUTF bar (HEBI) yang masing-masing secara berurutan mengandung kadar karbohidrat sebesar 51,5 g dan 42,5 g (Nga et al., 2013; Sigh et al., 2018).

Kadar air, abu, protein dan lemak mempengaruhi kandungan karbohidrat formula terpilih. Semakin rendah kandungan air, abu, protein dan lemak maka kadar karbohidrat menjadi semakin meningkat (Sihab et al., 2017). Bahan pangan yang berkontribusi terhadap kandungan karbohidrat formula terpilih adalah tepung kacang hijau, tepung beras, susu full cream, maltodekstrin dan gula halus.

Asupan energi sangat penting untuk balita yang mengalami masalah malnutrisi akut karena berperan dalam meningkatkan berat badan balita dan menunjang proses pertumbuhan, perkembangan dan metabolisme tubuh balita (Diniyyah \& Nindya, 2017). Hasil analisis kandungan energi produk $R U T F$ formula terpilih per 100 gram adalah sebesar $522 \mathrm{kkal}$. Kandungan energi formula terpilih lebih tinggi dibandingkan dengan produk RUTF dalam bentuk wafer (NumTrey Wafer) yang mempunyai kandungan energi sebesar $506 \mathrm{kkal}$ (Sigh et al., 2018). Akan tetapi kandungan energi produk formula terpilih pada penelitian ini lebih rendah dibandingkan dengan produk RUTF bar (HEBI) yang memiliki kandungan energi sebesar 544 kkal (Nga et al., 2013) dan 547 kkal (Wieringa et al., 2013). Selain itu, kandungan energi formula terpilih juga lebih rendah dibandingkan dengan produk RUTF dalam bentuk biskuit bar (BP-100) yang memiliki kandungan energi sebesar 529 kkal (Sigh et al., 2018).

Kandungan lemak, protein, dan karbohidrat sangat mempengaruhi kandungan energi. Kandungan lemak produk $R U T F$ formula terpilih merupakan penyumbang energi terbesar dan dilanjutkan dengan kandungan karbohidrat dan protein. Meskipun pada formula terpilih kandungan lemak menjadi penyumbang energi terbesar, hanya saja kandungan lemaknya lebih sedikit dibandingkan dengan penelitian sebelumnya (HEBI dan BP-100).

Konsumsi serat pangan pada balita harus dibatasi dan dalam jumlah yang rendah karena konsumsi serat yang tinggi dapat meningkatkan rasa kenyang, penurunan daya cerna energi dan zat gizi lain, serta mempersingkat waktu transit gastrointestinal. Sebuah penelitian menunjukkan pemberian makanan tinggi serat ( $13 \mathrm{~g} /$ hari) pada bayi dan anak-anak di Belanda menunjukkan penurunan penambahan berat badan dan pertumbuhan linear dibandingkan kelompok kontrol (Michaelsen et al., 2009). Kandungan serat pangan produk formula terpilih sebesar $4,66 \%$ dan sudah memenuhi standar produk $R U T F$. Kandungan serat pangan produk formula 
terpilih lebih tinggi dibandingkan dengan produk RUTF dalam bentuk wafer (NumTrey Wafer) yang mempunyai kadar serat pangan sebesar $1.1 \mathrm{~g}$ (Sigh et al., 2018). Bahan pangan yang berkontribusi terhadap kandungan serat pangan produk formula terpilih adalah tepung kacang hijau $(3,69 \mathrm{~g} / 100 \mathrm{~g})$ dan tepung beras $(2,4 \mathrm{~g} / 100 \mathrm{~g})$ (Mubarak, 2005; USDA, 2018).

Menurut Michaelsen et al., (2009), asupan zat besi sangat penting untuk balita yang mengalami malnutrisi akut berat, kekurangan asupan zat besi yang parah dapat menyebabkan keterbelakangan perkembangan mental. Zat besi memiliki peranan penting dalam transportasi oksigen, dan penting untuk fungsi imun, fungsi otak dan perkembangan otak. Kandungan zat besi pada formula terpilih sebesar 13,82 mg/100g. Kandungan zat besi produk formula terpilih pada penelitian ini lebih tinggi dibandingkan dengan produk RUTF dalam bentuk wafer (NumTrey Wafer), RUTF bar (HEBI) dan produk RUTF dalam bentuk biskuit bar / BP$100(10 \mathrm{mg} / 100 \mathrm{~g})$ dengan masing-masing produk secara berurutan mengandung zat besi per $100 \mathrm{~g}$ sebesar 5,8 mg, $8 \mathrm{mg}$ dan $10 \mathrm{mg}$ (Nga et al., 2013; Sigh et al., 2018).

Bahan pangan yang berkontribusi terhadap kandungan zat besi formula terpilih adalah paling banyak vitamin mineral mix dan tepung kacang hijau, selain itu tepung beras dan susu full cream juga berkontribusi terhadap kandungan zat besi. Kandungan zat besi per $100 \mathrm{~g}$ dari bahan-bahan tersebut adalah vitamin mineral mix sebesar 1656,4 $\mathrm{mg}$, tepung kacang hijau sebesar 7,73 $\mathrm{mg}$, tepung beras $0,35 \mathrm{mg}$ dan susu bubuk full cream $0,47 \mathrm{mg}$ (Mubarak, 2005; USDA, 2018).

Kalsium memiliki peran dalam pertumbuhan dan perkembangan tulang serta berperan dalam pengaktifan enzim yang terlibat pada pencernaan lemak, protein dan produksi energi (Sharlin \& Edelstein, 2014). Selain itu, asupan kalsium juga diperlukan untuk mencegah terjadinya rakhitis pada balita (Witte \& Fischer, 2020). Produk RUTF formula terpilih mengandung kalsium sebesar $348,24 \mathrm{mg} / 100 \mathrm{~g}$. Kandungan kalsium formula terpilih lebih tinggi dibandingkan dengan produk RUTF dalam bentuk wafer (NumTrey Wafer) yang mempunyai kadar kalsium sebesar $219 \mathrm{mg}$ (Sigh et al., 2018). Akan tetapi lebih rendah dibandingkan dengan produk RUTF dalam bentuk biskuit bar
(BP-100) yang memiliki kandungan kalsium sebesar 470 mg/100 g (Sigh et al., 2018). Bahan pangan vitamin mineral mix dan susu full cream memiliki kontribusi yang lebih besar terhadap kandungan kalsium jika dibandingkan dengan tepung kacang hijau dan tepung beras. Kandungan kalsium per $100 \mathrm{~g}$ dari bahan-bahan tersebut adalah vitamin mineral mix sebesar 9938,65 mg, susu bubuk full cream $912 \mathrm{mg}$, tepung kacang hijau sebesar 71,92 mg, dan tepung beras 10,00 mg.

Kualitas protein yang tinggi dalam suatu produk sangat dianjurkan dikonsumsi oleh balita yang mengalami malnutrisi akut berat dan kualitas protein dapat diukur melalui daya cerna protein produk. Berdasarkan hasil analisis, daya cerna protein produk RUTF formula terpilih yaitu sebesar $94,93 \%$. Nilai daya cerna protein produk RUTF berbentuk bar formula terpilih lebih dari $80 \%$ dan tergolong memiliki daya cerna protein yang tinggi (Kaspchak et al., 2018). Penggunaan pangan sumber protein hewani pada produk (susu full cream) yang tinggi menjadi salah satu faktor yang menyebabkan daya cerna protein produk tinggi. Serat pangan dan proses pengolahan dalam bentuk pemanasan dapat menyebabkan penurunan daya cerna protein. Akan tetapi, pada penelitian ini tidak menyebabkan penurunan yang cukup banyak dikarenakan kandungan serat pangan tidak tinggi dan proses pemanasan yang tidak terlalu lama.

Aktivitas air $\left(\mathrm{a}_{\mathrm{w}}\right)$ merupakan air yang bebas dalam suatu produk dan nilainya mempengaruhi pertumbuhan atau metabolisme mikroba pada produk tersebut (Asiah et al., 2018; Vesterlund et al., 2012). Aktivitas air dapat memprediksi keamanan dan stabilitas yang berhubungan dengan pertumbuhan mikroba, laju reaksi kimia dan biokimia, serta sifat fisik produk (Panja et al., 2019). Produk RUTF secara umum memiliki aktivitas air yang rendah yaitu berkisar antara 0,2-0,6 (FAO, 2015). Berdasarkan hasil analisis aktivitas air $\left(\mathrm{a}_{\mathrm{w}}\right)$ formula terpilih diperoleh nilai aktivitas air yang rendah yaitu 0,21 . Produk RUTF dengan nilai aktivitas air $0,20-0,45$ menunjukkan hasil yang baik terhadap stabilitas vitamin larut lemak dan lemak (FAO, 2019). Aktivitas air produk formula terpilih lebih rendah dibandingkan dengan beberapa produk $R U T F$ lainnya seperti RUTF berbentuk pasta yaitu berkisar 0,24-0,29 (Santini et al., 2013). Hal ini disebabkan karena 
pengunaan bahan seperti maltodekstrin dan proses pengolahan produk seperti penyangraian yang dapat mengurangi nilai aktivitas air produk (Badola et al., 2017).

\section{KESIMPULAN DAN SARAN}

Pengembangan produk $R U T F$ berbahan kacang hijau, serealia, dan minyak nabati diperoleh formula A1B1 (kombinasi kacang hijau dengan beras dan minyak kelapa) sebagai formula terpilih. Hasil analisis produk formula A1B1 berpotensi dijadikan sebagai produk RUTF alternatif untuk balita malnutrisi akut berat. Hal ini dapat dilihat dari kadar abu, protein, lemak, karbohidrat, energi, serat pangan, zat besi, kalsium, daya cerna protein dan aktivitas air sudah memenuhi standar yang dianjurkan untuk produk RUTF kecuali kadar air berdasarkan standar umum produk RUTF (WHO 2007).

Perlu adanya proses pengolahan bahan pangan dengan cara ekstruksi untuk membantu kadar air lebih rendah dan memenuhi standar umum produk RUTF berdasarkan WHO (2007) serta diperlukan penelitian lanjut terkait dengan uji daya terima produk penelitian kepada kelompok sasaran yaitu balita malnutrisi akut berat.

\section{DAFTAR PUSTAKA}

AOAC. (2005). Official Methods of Analysis of $A O A C$ International (18th ed.). Washington : Asociation of Official of Analytical Chemist International.

Andarwulan, N., Kusnandar, F., \& Herawati, D. (2011). Analisis Pangan. Jakarta : Dian Rakyat.

Asiah, N., Cempaka, L., \& David, W. (2018). Pendugaan Umur Simpan Produk Pangan. Jakarta : UB Press.

Badola, R., Singh, R. R. B., Panjagari, N. R., Singh, A. K., \& Hussain, S. A. (2017). Effect of selected humectants as water activity modifiers on the quality of model khoa system. Indian $J$ Dairy Sci, 70(2), 145-154.

Boateng, L., Ansong, R., Owusu, W. B., \& Steiner-Asiedu, M. (2016). Coconut oil and palm oil's role in nutrition, health and national development: A review. Ghana Medical Journal, 50(3), 189-196. doi: 10.4314/gmj.v50i3.11
Budiarti, A. E., Ansharullah, \& Karimuna, L. (2017). Pengaruh substitusi tepung jagung (Zea mays. L) terfermentasi terhadap karakteristik organoleptik dan nilai gizi cake tulban. $J$ Sains Dan Teknologi Pangan, 2(3), 508-519.

Ciliberto, M. A., Sandige, H., Ndekha, M. J., Ashorn, P., Briend, A., Ciliberto, H. M., \& Manary, M. J. (2005). Comparison of homebased therapy with ready-to-use therapeutic food with standard therapy in the treatment of malnourished Malawian children: a controlled, clinical effectiveness trial. American Journal of Clinical NUtrition, 81(4), 864-870. doi: 10.1093/ajcn/81.4.864

Dahiya, P. K., Nout, M. J. R., van Boekel, M. A., Khetarpaul, N., Grewal, R. B., \& Linnemann, A. (2014). Nutritional characteristics of mung bean foods. British Food Journal, 116(6), 1031-1046. doi: 10.1108/BFJ-11-2012-0280

Diniyyah, S. R., \& Nindya, T. S. (2017). Asupan Energi, Protein dan Lemak dengan Kejadian Gizi Kurang pada Balita Usia 24-59 Bulan di Desa Suci, Gresik. Amerta Nutr, 341-350. doi: 10.2473/amnt.v1i4.2017.341-350

Dipasquale, V., Cucinotta, U., \& Romano, C. (2020). Acute malnutrition in children: Pathophysiology, clinical effects and treatment. Nutrients, 12(8), 2413-2421. doi: 10.3390/nu12082413

FAO. (2015). Codex alimentarius comission, joint FAO/WHO food standards programme codex committee on nutrition and foods for special dietary uses : Discussion paper on a standard for ready to-use foods. Germany : Food and Agriculture Organization.

FAO. (2019). Codex alimentarius comission, joint FAO/WHO food standards programme codex committee on nutrition and foods for special dietary uses : proposed Draft Guideline for Ready to Use Therapeutic Foods Section 5.2.2 (Food Additive) and Section 6.2 (Protein). Italy : Food and Agriculture Organization.

Hendrixson, D. T., Godbout, C., Los, A., CallaghanGillespie, M., Mui, M., Wegner, D., Bryant, T., Koroma, A., \& Manary, M. J. (2020). Treatment of severe acute malnutrition with oat or standard ready-to-use therapeutic food: A triple-blind, randomised controlled clinical trial. Gut, 69(12), 2143-2149. doi: 10.1136/gutjnl-2020-320769

Hou, D., Yousaf, L., Xue, Y., Hu, J., Wu, J., Hu, X., Feng, N., \& Shen, Q. (2019). Mung bean (Vigna radiata L.): Bioactive polyphenols, polysaccharides, peptides, and health 
benefits. Nutrients, 11(6), 1-28. doi:10.3390/ nu11061238

Kaspchak, E., Mafra, L. I., \& Mafra, M. R. (2018). Effect of heating and ionic strength on the interaction of bovine serum albumin and the antinutrients tannic and phytic acids, and its influence on in vitro protein digestibility. Food Chemistry, 252, 1-31. doi:10.1016/j. foodchem.2018.01.089

Kemenkes. (2018). Hasil utama Riskesdas 2018. Jakarta : Kementrian Kesehatan Republik Indonesia.

Khan, R.H., Shiddiqi, M. K., \& Salahuddin, P. (2017). Protein structure and function. Https://Www. Researchgate.Net/Publication/316139245 Protein_Structure_and_Function. Retrieved from https://www.researchgate.net/ publication/316139245_Protein_Structure_ and Function

Lenters, L., Wazny, K., \& Bhutta, Z. A. (2016). Management of Severe and Moderate Acute Malnutrition in Children. Washington: The World Bank.

Linneman, Z., Matilsky, D., Ndekha, M., Manary, M. J., Maleta, K., \& Manary, M. J. (2007). A large-scale operational study of home-based therapy with ready-to-use therapeutic food in childhood malnutrition in Malawi. Maternal and Child Nutrition, 3, 206-215.

Michaelsen, K. F., Hoppe, C., Roos, N., Kaestel, P., Stougaard, M., Lauritzen, L., Molgaard, C., Girma, T., \& Friis, H. (2009). Choice of foods and ingredients for moderately malnourished children 6 months to 5 years of age. Food and Nutrition Bulletin, 30(3), 343-404. doi: 10.1177/15648265090303s303

Miele, N. A., Armini, V., Troccoli, A. M., Puleo, S., Paduano, A., Sacchi, R., \& Cavella, S. (2020). Sensory evaluation and volatile compounds of an alternative ready-to-use therapeutic food for malnourished children. Journal of Food Science, 85(4), 1265-1273. doi: 10.1111/17503841.15110

Mikołajczak, N. (2017). Coconut oil in human diet-nutrition value and potential health benefits. Journal of Education, 7(9), 307-319. https://doi. org/10.5281/zenodo.997464

Mubarak, A. E. (2005). Nutritional composition and antinutritional factors of mung bean seeds (Phaseolus aureus) as affected by some home traditional processes. Food Chemistry, 89(4), 489-495. doi: 10.1016/j. foodchem.2004.01.007
NDPC. (2016). Social and Economic Impact of Child Undernutrition on Ghana's Long-Term Development. Retrieved from. https://reliefweb. int/sites/reliefweb.int/files/resources/GHANA. pdf

Nga, T. T., Nguyen, M., Mathisen, R., Hoa, D. T. B., Minh, N. H., Berger, J., \& Wieringa, F. T. (2013). Acceptability and impact on anthropometry of a locally developed Readyto-use therapeutic food in pre-school children in Vietnam. Nutrition Journal, 12(120), 1-8. doi: 10.1186/1475-2891-12-120

Nielsen, S. S. (2010). Food Analysis (Fourth). West Lafayette: Springer. Retrieved from www. springer.com/series/5999

Nurhusna, A., Marliyati, A., \& Palupi, E. (2020). Snack bar made from sorghum and beans wuth addtion of red palm oil as suplementary food for pregnant women with chronic energy deficiency. Media Gizi Indonesia, 15(3), 173-183. doi: 10.204736/mgi.v15i3

Oakley, E., Reinking, J., Sandige, H., Trehan, I., Kennedy, G., Maleta, K., \& Manary, M. (2010). A ready-to-use therapeutic food containing 10\% milk is less effective than one with $25 \%$ milk in the treatment of severely malnourished children. Journal of Nutrition, 140(12), 2248-2252. doi: 10.3945/jn. 110.123828

Owino, V. O., Irena, A. H., Dibari, F., \& Collins, S. (2012). Development and acceptability of a novel milk-free soybean-maize-sorghum ready-to-use therapeutic food (SMS-RUTF) based on industrial extrusion cooking process. Maternal and Child Nutrition, 10(1), 126-134. doi: 10.1111/j.1740-8709.2012.00400.x

Panja, P., Deepika, \& Bhattacharjee, D. (2019). An overview of the principles and effects of intermediate moisture fruits and vegetables. International Journal of Chemical Studies, 3(6), 848-855. Retrived from http://www. chemijournal.com

Rohman, A., Helmiyati, S., Hapsari, M., \& Setyaningrum, D. L. (2014). Rice in health and nutrition. International Food Research Journal, 21(1), 13-24.

Santini, A., Novellino, E., Armini, V., \& Ritieni, A. (2013). State of the art of ready-to-use therapeutic food: A tool for nutraceuticals addition to foodstuff. Food Chemistry, 140(4), 843-849. doi: 10.1016/j.foodchem.2012.10.098

Saunders, R. M., Connor, M. A., Booth, A. N., Bickoff, E. M., \& Kohler, G. O. (1973). Measurement of digestibility of alfafa protein 
concentrates by in vivo and in vitro methods. J. Nutr, 103(4), 530-535. doi: 10.1093/ jn $/ 103.4 .530$

Shah, T. R., Prasad, K., \& Kumar, P. (2016). Maize-a potential source of human nutrition and health: a review. Cogent Food \& Agriculture, 2(1), 1-9. doi: 10.1080/23311932.2016.1166995.

Sharlin, J., \& Edelstein, S. (2014). Buku Ajar Gizi dalam Daur Kehidupan (C. A. Agustin, E. Rezkina, \& Q. Rahmah (eds.)). Jakarta : EGC.

Sigh, S., Roos, N., Chamnan, C., Laillou, A., Prak, S., \& Wieringa, F. T. (2018). Effectiveness of a locally produced, fish-based food product on weight gain among cambodian children in the treatment of acute malnutrition: A randomized controlled trial. Nutrients, 10(7), 1-17. doi 10.3390/nu10070909

Sihab, Karimuna, L., \& Tamrin. (2017). Pengaruh formulasi tepung beras dan tepung ubi kayu fermentasi dengan penambahan maltodekstrin terhadap penilaian organoleptik dan kandungan gizi keripik bayam (Amaranthus spp). J Sains Dan Teknologi Pangan, 2(3), 575-589.

UNICEF. (2013). Improving Child Nutrition: The achievable imperative for global progress. New York : United Nations Children's Fund.

UNICEF. (2019). Product spesification sheet RUTF biscuit (BP-100). New York: United Nations Children's Fund.

UNICEF. (2020). COVID-19 and Children in Indonesia. Jakarta : United Nations Children's Fund. Retrieved from https://www.unicef.org/ indonesia/sites/unicef.org.indonesia/files/202005/COVID-19-and-Children-in-Indonesia2020 0.pdf

USDA. (2018). Rice flour, white. National Nutrient Database for Standar Reference. Retrieved from https://fdc.nal.usda.gov/fdc-app.html\#/fooddetails/169714/nutrients

Vala, G. S., \& Kapadiya, P. K. (2014). Medicinal benefits of coconut oil (a review paper). International Journal of Life Sciences Research, 2(4), 124-126. Retrieved from https://www. researchgate.net/publication/268805677
Vesterlund, S., Salminen, K., \& Salminen, S. (2012). Water activity in dry foods containing live probiotic bacteria should be carefully considered: A case study with Lactobacillus rhamnosus GG in flaxseed. International Journal of Food Microbiology, 157(2), 319321. doi: 10.1016/j.ijfoodmicro.2012.05.016.

Villanueva, N. D. M., Petenate, A. J., \& Da Silva, M. A. A. P. (2005). Performance of the hybrid hedonic scale as compared to the traditional hedonic, self-adjusting and ranking scales. Food Quality and Preference, 16(8), 691-703. doi: 10.1016/j.foodqual.2005.03.013.

WHO. (2007). Community-based management of severe acute malnutrition. Geneva : World Health Organization.

WHO. (2010). Nutrition Landscape Information System (NLIS) Country Profile indicators. Geneva : World Health Organization.

Wieringa, F. T., Tran, N. T., Hoang, M.-A., Brown, M., Maalouf-Manasseh, Z., Lu'u, T. T. M., Nguyen, M. T. H., Hop, L. T., \& Berger, J. (2013). Acceptability of Two Ready-to-Use Therapeutic Foods among HIV Positive Patients in Vietnam. Washington: FHI 360. Retrieved from https://www.researchgate.net/ publication/321758805.

Winarno, F. (2008). Kimia Pangan dan Gizi. Jakarta : M-Brio Press.

Witte, M. A., \& Fischer, P. R. (2020). Severe acute malnutrition, calcium and vitamin D: Important interactions. Public Health Nutrition, 23(17), 3187-3189. Doi: 10.1017/ S1368980020002499.

Wu, T., Wang, L., Li, Y., Qian, H., Liu, L., Tong, L., Zhou, X., Wang, L., \& Zhou, S. (2019). Effect of milling methods on the properties of rice flour and gluten-free rice bread. LWT-Food Science and Technology, 108, 137-144. doi: 10.1016/j. lwt.2019.03.050.

Yi-Shen, Z., Shuai, S., \& Fitzgerald, R. (2018). Mung bean proteins and peptides: Nutritional, functional and bioactive properties. Food and Nutrition Research, 62, 1-11. doi:10.29219/ fnr.v62.1290. 